\title{
Karakteristik Buah Dan Biji Cabai Rawit (Capsicum frustescens L.) Yang Diberi Pupuk Organik Cair Rebung Bambu Terfermentasi Ragi Tempe
}

\section{Characteristics of Fruits and Seeds of Cayenne Pepper (Capsicum frustescens L.) Given Liquid Organic Fertilizer of Bamboo Shoots Fermented Tempe Yeast}

\author{
Antonius Buksalwembun ${ }^{1}$, Vivin Andriani² \\ 1,2Prodi Biologi FST Universitas PGRI Adi Buana Surabaya. \\ Email: antonbuksalw@gmail.com ${ }^{1}$, v.andriani@unipasby.ac.id ${ }^{2}$
}

\begin{abstract}
Abstrak
Tanaman cabai rawit (Capsicum frustescens L.) merupakan salah satu tanaman sayuran yang penting bagi masyarakat sebagai penambah cita rasa dalam masakan sehari-hari. Tujuan penelitian ini adalah untuk mengetahui pengaruh pemberian pupuk organik cair rebung bambu terfermentasi ragi tempe terhadap karakteristik buah dan biji serta hasil panen cabai rawit. Penelitian ini bersifat eksperimen menggunakan RAL dengan 4 perlakuan $0 \mathrm{ml} / \mathrm{l}$, $5 \mathrm{ml} / \mathrm{l}, 10 \mathrm{ml} / \mathrm{l}$ dan $15 \mathrm{ml} / 1$ pupuk organik cair rebung bambu terfermentasi ragi tempe 6 kali ulangan. Hasil penelitian ini menunjukkan bahwa produksi buah cabai rawit dengan konsentrasi $10 \mathrm{ml} / 1$ menghasilkan produksi jumlah buah terbaik dengan rata-rata 68,17 gram dan dapat mereduksi jumlah biji cabai rawit sebesar 1.584 biji.
\end{abstract}

Kata Kunci : Cabai rawit (Capsicum frustescens L.); rebung bambu; fermentasi; ragi tempe; produksi.

\begin{abstract}
Cayenne pepper (Capsicum frustescens L.) is one of the important vegetable crops for the community as a flavor enhancer in daily cooking. The purpose of this study was to determine the effect of liquid organic fertilizer application offermented tempeh bamboo yeast on the characteristics of fruit and seeds as well as yields of cayenne pepper. This research was experimental using RAL with 4 treatments of $0 \mathrm{ml} / l, 5 \mathrm{ml} / \mathrm{l}, 10 \mathrm{ml} / \mathrm{l}$ and $15 \mathrm{ml} / \mathrm{lof}$ liquid organic fertilizer, fermented bamboo shoots, fermented tempeh, 6 times. The results of this study showed that the production of cayenne pepper with a concentration of $10 \mathrm{ml} / \mathrm{l}$ resulted in the production of the best number of fruits with an average of 68.17 grams, while there was a study of the number of seeds showing that a concentration of $10 \mathrm{ml} / \mathrm{l}$ produced the best number of seeds with an average of 1.584 .
\end{abstract}

Keywords : Cayenne pepper (Capsicum frustescens L.); bamboo shoots; fermentation; tempeh yeast; production. .

\section{PENDAHULUAN}

Tanaman cabai rawit (Capsicum frustescens L.) merupakan salah satu tanaman sayuran yang penting bagi masyarakat sebagai penambah cita rasa dalam masakan sehari-hari. Jenis tanaman sayuran ini memiliki ciri yaitu mempunyai rasa yang pedas dan aroma yang khas. Menurut Rukmana (2002), cabai rawit terkandung zat gizi yaitu lemak, protein, karbohidrat, kalsium, fosfor, besi, vitamin A, B1, B2, C dan senyawa alkaloid seperti capsicin oleoresin, flavanoid dan minyak esensial.

Produksi tanaman cabai rawit ini di Jawa Timur dari tahun 2012 hingga dengan tahun 2016 berfluktuasi namun cenderung mengalami penurunan. Pada tahun 2012 produksi tanaman cabai rawit sebesar 244,040 ton, sedangkan pada periode tahun
2013 mengalami penurunan menjadi

227,486 ton. Pada tahun 2014-2016 mengalami kenaikan menjadi 260,803 ton (BPS, 2017). Selain itu cabai rawit setiap tahun mengalami peningkatan konsumen dan di pasaran harga cabai rawit meningkat. Hal ini dikarenakan tidak sedikit petani yang mengalami gagal panen.

Faktor penunjang pertumbuhan dan perkembangan tanaman adalah unsur hara. Unsur hara dapat meningkat menggunakan pupuk kimia. Penggunaan pupuk ini tidak hanya berdampak positif tapi memberi dampak negatif apabila digunakan secara terus-menerus dan dalam waktu yang relatif lama. Penggunaan bahan organik merupakan salah satu cara dalam bidang pertanian yang dilakukan untuk mengatasi penggunaan pupuk kimia yaitu meningkatkan penggunaan bahan organik. 
Unsur makro dan mikro yang terkandung dalam pupuk organik dibutuhkan suatu tanaman. Tanaman dapat memanfaatkan Unsur-unsur organik di dalam pupuk setelah melalui proses dekomposisi di dalam tanah (Parnata dan Ayub, 2010). Salah satu bahan organik yang dapat digunakan sebagai pupuk cair organik adalah rebung bambu.

Bambu adalah tanaman dengan pertumbuhan yang sangat cepat, daya kecepatan tumbuh yang dimiliki bambu inilah menjadi faktor utama dalam memanfaatkan rebung bambu sebagai pupuk organik atau secara umum digunakan bahan MOL (mikro organisme lokal). Dalam 100 gram rebung bambu mengandung senyawa yang dibutuhkan tumbuhan yaitu $59 \mathrm{mg}$ fosfor, $13 \mathrm{mg}$ kalsium, 0,50 mg besi, $90 \mathrm{mg}$ abu, $533 \mathrm{mg}$ kalium (Watt dan Merill, 1975). Proses fermentasi menggunakan ragi tempe untuk mengubah senyawa kompleks menjadi senyawa yang sederhana sehingga tanmaan dapat menyerap nutrisi yang diberikan dengan baik. Ragi tempe mengandung mikroba jamur yang berpotensi sebagai pengirai unsur hara (Yuwono, 2006).

\section{METODE PENELITIAN \\ Waktu dan Tempat}

Penelitian ini dilakukan di Green House Prodi Biologi FST Universitas PGRI Adi Buana Surabaya pada bulan Mei-Juli 2020.

\section{Bahan dan Alat}

Bahan yang digunakan dalam penelitian ini meliputi bibit tanaman cabai rawit yang berumur 10 hari, rebung bambu $1,5 \mathrm{~kg}$, ragi tempe 10 gram serta media tanam (tanah $0,5 \mathrm{~kg}$ per polybag) dan pupuk dasar $0,5 \mathrm{~kg}$. Alat-alat yang diperlukan yaitu blender, gerigen besar 30 liter, $\mathrm{pH}$ meter, timbangan digital, gelas ukur, polybag 25x25 dan sprayer ukuran 1 liter.

\section{Rancangan Penelitian}

Penelitian ini menggunakan metode

Rancangan Acak Lengkap (RAL), kemudian penelitian ini dilanjutkan dengan uji $\mathrm{F}$ (ANOVA), apabila berbeda nyata maka akan dilanjutkan dengan Uji Beda (Beda Nyata Terkecil). Pada penelitian ini menggunakan 4 perlakuan konsentrasi pupuk cair organik rebung bambu $0 \%, 5 \%$, $10 \%, 15 \%$ dan dilakukan 6 pengulangan untuk diaplikasikan pada tanaman cabai rawit. Penelitian ini menggunakan pupuk organik cair rebung bambu jenis bambu tali terfermentasi ragi tempe yang diharapkan dapat meninjau karakteristik buah dan biji serta hasil produksi tanaman cabai rawit (Capsicum frustescens L.).

\section{Analisis Data}

Data hasil pengamatan akan dianalisis menggunakan analisis of varian sesuai dengan rancangan percobaannya pada signifikan 0,5. Uji lanjutan akan menggunakan uji BNT pada taraf 0,05 jika terdapat pengaruh yang signifikan dari pupuk organik cair rebung bambu terfermentasi ragi tempe.

\section{Prosedur Penelitian \\ Persemaian Benih}

Proses persemaian dengan melakukan pengolahan lahan persemaian dengan menyiapkan nampan plastik dan diisi dengan tanah yang dicampur dengan pupuk dasar perbandingan 2:1. Kemudian diamkan lahan persemaian selama 2 hari setelah itu taburkan benih cabai rawit yang layak ditanam dan ditutup tanah tipis-tipis. Persemaian disiram secara rutin tiap hari yaitu pada sore hari dengan menggunakan sprayer 1 liter.

\section{Pembuatan POC Rebung Bambu}

Rebung bambu sebanyak $1,5 \mathrm{~kg}$ dan ditambahkan air sebanyak $1000 \mathrm{ml}$ kemudian di blender hingga halus setelah itu diamkan selama 20 menit agar mikroorganisme berkembang. Rebung yang telah halus diberi ragi tempe 10 gram, campurkan secara merata hingga homogen, masukan ke dalam gerigen ditutup dengan rapat. Bahan-bahan yang telah tercampur di fermentasi selama 2 minggu dengan suhu ruangan yaitu sekitar $37^{0} \mathrm{C}$, setelah 2 
minggu larutan pupuk organik cair rebung bambu sudah siap digunakan. Pupuk cair dibagi sesuai konsentrasi yang sudah ditentukan yaitu $5 \mathrm{ml} / 100 \mathrm{ml}, 10 \mathrm{ml} / 100 \mathrm{ml}$ dan $15 \mathrm{ml} / 100 \mathrm{ml}$.

\section{Penyiraman}

Proses penyiraman dilakukan setiap sore hari dan pemberian pupuk dilakukan setiap satu minggu sekali dengan kosentrasi $5 \mathrm{ml} / 100 \mathrm{ml}, 10 \mathrm{ml} / 100 \mathrm{ml}$ dan $15 \mathrm{ml} / 100$ $\mathrm{ml}$ selama tiga bulan.

\section{Pengamatan}

Proses pengamatan dilakukan setiap minggu sampai tanaman berumur tiga bulan setelah masa tanam diantaranya: jumlah buah dan jumlah biji.

\section{HASIL DAN PEMBAHASAN}

Tanaman cabai rawit setelah 3 bulan dapat dipanen dan dihitung jumlah buah dan jumlah biji sesuai konsentrasi yaitu 5 $\mathrm{ml} / 100 \mathrm{ml}, 10 \mathrm{ml} / 100 \mathrm{ml}$ dan $15 \mathrm{ml} / 100 \mathrm{ml}$.

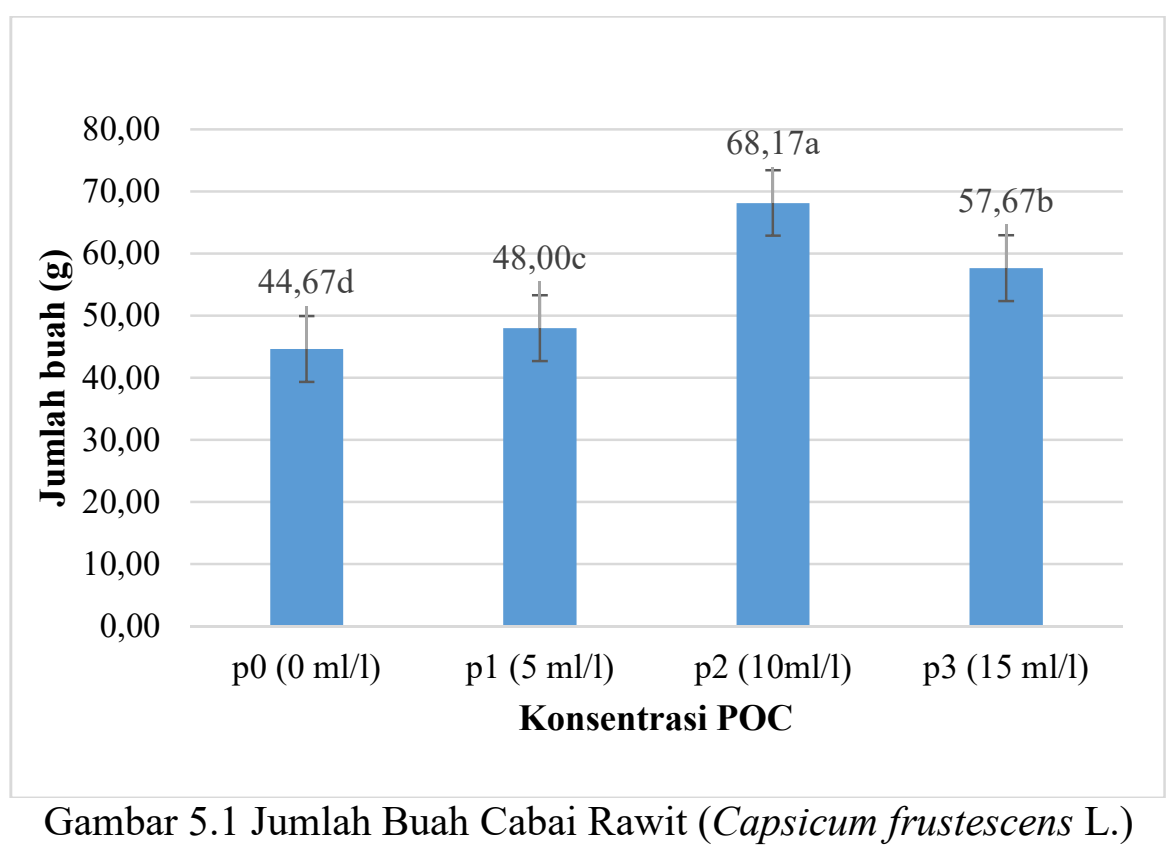

\section{Jumlah Buah Cabai Rawit}

Data hasil pengamatan jumlah buah tanaman cabai rawit selama 3 bulan dilihat gambar 5.1 terdapat hasil yang signifikan pada penggunaan pupuk organik cair rebung bambu terfermentasi ragi tempe. Pada gambar 5.1 menunjukan terdapat perbedaan rata-rata jumlah buah cabai rawit. Pada perlakuan P2 dengan konsentrasi $10 \mathrm{ml} / 1$ memperlihatkan hasil yang lebih tinggi dibandingkan dengan P0 $0 \%$, P1 5\% dan P3 15\% tetapi perbedaan ini menunjukan hasil yang signifikan pada taraf 0,05 . Peningkatan jumlah buah cabai rawit ini sejalan dengan penelitian Andriani, (2020), yang menunjukkan bahwa hasil panen tanaman cabai rawit meningkat setelah pemberian sari rebung bambu pada konsentrasi 13,5 ml/1.
Menurut Nugroho (2013) kadar nutrisi rebung bambu mengandung komposisi yang meliputi unsur makro dan mikro. Rebung bambu mengandung fosfor $59 \mathrm{mg}$, kalsium $13 \mathrm{mg}$, besi $0,50 \mathrm{mg}$, dan kalium 20,15 mg yang diperlukan pada tanaman. Perubahan jumlah bush tanaman pada perlakuan konsentrasi dikarenakan kandung P memiliki takaran dan komposisi yang cukup. Hal ini menyebabkan jumlah nutrisi pada perlakuan P2 lebih tinggi dibandingkan dengan perlakuan yang lain sehingga kandungan $\mathrm{P}$ dan $\mathrm{K}$ mengakibatkan jumlah buah cabai rawit berbeda.

Unsur $\mathrm{K}$ berperan sebagai media transportasi yang akan membawa unsur hara dari akar termasuk unsur $P$ ke daun dan mentranslokasi asimilat dari daun ke 
seluruh jaringan tanaman. Proses transportasi dalam tanaman akan terhambat apabila kurangnya unsur $\mathrm{K}$ pada tanaman. Oleh karena itu, unsur $\mathrm{K}$ dalam tanaman harus optimal agar proses transportasi unsur hara maupun asimilat dalam tanaman dapat berlangsung optimal (Taufiq, 2002). Unsur $\mathrm{K}$ dapat berperan dalam memelihara tekanan turgor dengan baik sehingga memungkinkan proses-proses metabolisme dan menjamin kesinambungan pemanjangan sel menjadi lancar (Ainun, 2011). Perakaran tanaman dapat menyerap unsur hara $\mathrm{K}$ dalam bentuk kation $\mathrm{K}+$ (Fi'liyah, 2016).

Kandungan unsur fosfor dan kalsium yang terkandung dalam pupuk organik cair dapat membantu meningkat jumlah buah tanaman cabai rawit. Unsur P merupakan unsur yang berperan penting dalam proses fotosintesis, perkembangan akar, pembentukan bunga, buah dan biji (Simanungkalit, 2006). Berdasarkan Malherbe (1964) dalam Zubaidah dan Munir (2007) menyatakan unsur fosfor dapat mengaktifkan pertumbuhan bunga, mempercepat pematangan buah dan tanaman. Yasmin et al. (2014) menyatakan jumlah bunga yang banyak dapat meningkatkan jumlah buah terbentuk akan lebih banyak. Banyaknya peningkatan jumlah buah hasil panen per tanaman dapat di ikuti dengan peningkatan bobot segar per buah hal ini sesuai dengan Wijayanto et al. (2012) hasil penelitian sebelumnya pada tanaman semangka.

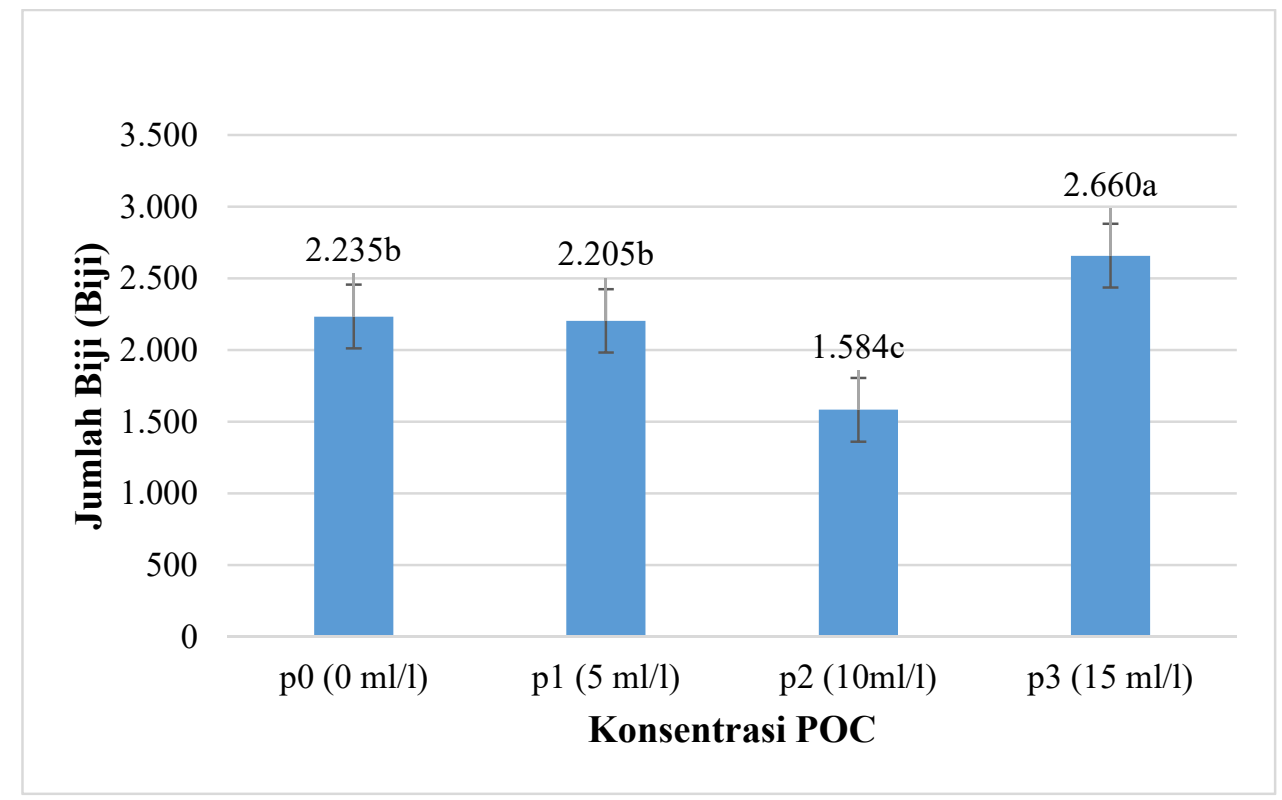

Gambar 5.4 Jumlah Biji Cabai Rawit (Capsicum frustescens L.)

\section{Jumlah Biji Cabai Rawit}

Data hasil pengamatan jumlah dan bobot biji tanaman cabai rawit selama 3 bulan dilihat gambar 5.4 terdapat hasil yang signifikan pada penggunaan pupuk organik cair rebung bambu terfermentasi ragi tempe. Pada gambar 5.4 menunjukan terdapat perbedaan rata-rata jumlah biji cabai rawit. Pada perlakuan P2 dengan konsentrasi $10 \mathrm{ml} / 1$ memperlihatkan hasil yang lebih rendah dibandingkan dengan $\mathrm{P} 0$ $0 \%$, P1 5\% dan P3 15\% tetapi perbedaan ini menunjukan hasil yang signifikan berdasarkan uji ANOVA. Hasil jumlah biji tanaman tertinggi terdapat pada perlakuan $0 \%$ (kontrol) dan hasil jumlah biji tanaman terendah terdapat pada perlakuan P2 10\%. Hasil perlakuan P2 10\% pada jumlah biji tanaman rendah hal ini disebabkan karena pemberian pupuk organik cair rebung bambu yang mengandung fitohormon giberelin. Hal ini sejalan dengan penelitian Isnaini et al. 2018 menyatakan penggunaan ekstrak rebung bambu menurunkan jumlah 
biji pada tanaman anggur 1,36 menurun sebesar 54\% dibanding kontrol.

Permatasari et al. (2016) menyatakan fitohormon giberelin dapat mencegah pembentukan biji buah dengan menghambat proses fertilisasi. Pardal (2001) fertilisasi akan digantikan oleh fitohormon giberelin dalam mengatur perubahan pada hormonal sel karena kemampuan fitohormon giberelin dapat menginduksi pembentukan hormon auksin dan bersinergi dengan hormon lainnya. Hal ini sejalan dengan penelitian Annisah (2009), pada buah semangka terbukti terhadap pembentukan buah tanpa biji (partenokarpi) dipengaruhi oleh fitohormon giberelin dengan konsentrasi hormon giberelin yang berbeda sehingga menghasilkan hasil yang berbeda pula.

Tanaman memproduksi biji yang banyak serta bobot biji yang tinggi memiliki tekstur biji yang keras dikarenakan kurangnya pemberian fitohormon giberelin hal ini sejalan dengan Nitsch (1950) dalam Annisah (2009) menyatakan frekuensi penyemprotan giberelin yang berkurang akan berdampak pada perkembangan buah.

Unsur hara pada POC meningkat dapat disebabkan dari proses fermentasi rebung bambu oleh ragi tempe. Proses fermentasi terjadi aktivitas mikroba jamur pengurai selulosa dan ragi dapat merombak unsur hara dalam pupuk organik cair sehingga mempengaruhi kenaikan unsur hara (Yuwono, 2006)

\section{KESIMPULAN}

Pupuk organik rebung bambu terfermentasi ragi tempe pada konsentrasi $10 \mathrm{ml} / \mathrm{L}$ memberikan hasil terbaik dalam jumlah buah dan mereduksi jumlah biji pada tanaman cabei rawit.

\section{SARAN}

Penelitian selanjutnya dapat dilakukan untuk mengetahui aplikasi pemberian pupuk organik cair rebung bambu terfermentasi ragi tempe terhadap kandungan vitamin $\mathrm{C}$ dan kandungan capsaisin.

\section{DAFTAR PUSTAKA}

Ainun, M, Nurhayati, Dewi, S. 2011 Pengaruh Pemberian Pupuk Organik dan Jenis Mulsa Organik Terhadap Pertumbuhan dan Hasil Kedelai (Glycine max L. Merrill). Jurnal Floratek. 6: $192-201$.

Andriani V. 2020. Sari Rebung Bambu Duri (Bambusa blumeana) Sebagai Fitohormon Giberelin Terhadap Pertumbuhan Dan Produksi Tanaman Cabai Rawit (Capsicum frutescents L.). Jurnal Pendidikan dan Biologi. 12(1): 57-61.

Annisah, 2009. Pengaruh Induksi Hormon Giberelin terhadap Pembentukan Buah Partenokarpi pada Beberapa Varietas Tanaman Semangka. Skripsi. Universitas Sumatera Utara.

Badan Pusat Statistik (BPS) Provinsi Jawa Timur, 2016. Analisis Data Bawang Merah dan Cabai Provinsi Jawa Timur. Dikutip dari : http://jatim.bps.go.id/

Fi'liyah, Nurjaya, Syekhfani. 2016. Penngaruh Pemberian Pupuk KCL Terhadap N, P, K Serapan Tanah dan Serapan Tanaman Pada Inceptisol, Untuk Tanaman Jagung di Situ Hilir, Cibungbulang, Bogor. Jurnal Tanah dan Sumberdaya Lahan. 3(2). 329337.

Isnaini, Mahadewi NNA, Artha IN. 2018. Upaya Perbaikan Kualitas Buah Anggur Bali (Vitis vinifera L. Var. Alphonso Lavallee) Melalui Aplikasi GA dari Ekstrak Rebung Bambu pada Stadia Bunga Mekar. The E-Journal of Tropical Agroecotechnology. 7(1): 2301-6515.

Nugroho, A. 2013. Meraup untung budidaya rebung. Pustaka Baru Press. Yogyakarta.

Pardal, S. J. 2001. Pembentukan buah partenokarpi melalui rekayasa genetika.Balai Penelitian 
Bioteknologi Tanaman Pangan, Bogor. Buletin AgroBio 4(2) : 4549.

Parnata, Ayub S. 2004. Pupuk Organik Cair Aplikasi dan Manfaatnya. Jakarta. Agromedia Pustaka. 112 hal.

Permatasari. 2016. Pengaruh Pemberian Hormon Giberelin Terhadap Pertumbuhan Buah Secara Partenokarpi pada Tanaman Tomat Varietas Tombatu F1.

Rukmana, R. 2002. Bertanam terong. Kanasius. Jogyakarta.

Simanungkalit. 2006. Pupuk Organik dan Pupuk Hayati. Bogor: Balai Besar Penelitian dan Pengembangan Sumber Daya Lahan Pertanian.

Taufiq, A. 2002. Status P dan K lahan kering tanah alfisol pulau Jawa dan Madura serta optimasi pemupukannya untuk tanaman kacang tanah. Prosiding Seminar Nasional dan Pertemuan Tahunan Komisariat Daerah Himpunan Ilmu Tanah Indonesia. Malang.
Watt, B. K. dan A.L. Merill. 1975. Handbook of The Nutritional Content of Food. Decker Publ., Inc., New York.

Wijayanto, T., W.O.R. Yani M.W. Arsana. 2012. Respon Hasil Jumlah Semangka (Citrullus vulgaris) dengan Aplikasi Hormon Giberelin (GA3). Jurnal Agroteknos. 2(1): 5762.

Yasmin, S,. T. Wardiati dan Koesriharti. 2014. Pengaruh Perbedaan Waktu Aplikasi dan Konsentrasi Giberelin (GA3) Terhadap Pertumbuhan dan Hasil Tanaman Cabai Besar (Capsicum annuum L.) Jurnal Produksi Tanaman. 2(5): 395-403.

Yuwono, T. 2006. Bioteknologi Pertanian. Seri Pertanian. Gadjah Mada University Press. 66 hal. 